UNIVERSITÉ DE LAUSANNE - FACULTÉ DE BIOLOGIE ET DE MÉDECINE DEPARTEMENT DE MÉDECINE Service de Dermatologie et Vénéréologie Chef de Service: Professeur Renato G. Panizzon

\title{
Pseudoxanthoma elasticum: \\ Evaluation of diagnostic criteria based on molecular data
}

\section{THÈSE}

Préparée sous la supervision du Dr Daniel Hohl, Professeur associé et présentée à la Faculté de biologie et de médecine de I'Université de Lausanne pour l'obtention du grade de

\section{DOCTEUR EN MÉDECINE}

par

Stéphanie Christen-Zäch

Médecin diplômée de la Confédération Suisse

Originaire de Lausanne

Lausanne 


\section{RÉSUMÉ EN FRANCAIS}

Introduction: Le pseudoxanthome élastique (PXE) est une maladie génétique. Les mutations responsables ont été localisées au niveau du gène codant le transporteur transmembranaire ABC-C6. Des calcifications pathologiques des fibres élastiques de la peau, des yeux et du système cardiovasculaire en sont la conséquence.

Buts: Evaluer les critères diagnostiques actuels du PXE en se basant sur les données moléculaires.

Méthodes: 142 sujets provenant de 10 familles avec une anamnèse familiale positive pour le PXE ont été investiguées sur le plan clinique, histopathologique et génétique.

Résultats: 25 sujets se sont avérés être homozygotes pour le gène PXE muté. 23 d'entre eux ont présenté les manifestations cliniques et histopathologique typiques. Les deux autres souffraient d'une élastose et d'une dégénérescence maculaire si importante qu'un diagnostic de PXE ne pouvait pas être confirmé cliniquement. 67 sujets se sont révélés être des porteurs hétérozygotes et 50 ne présentaient pas de mutation. De ces 117 sujets, 116 n'ont montré aucune lésion cutanée ou ophtalmique pouvant correspondre au PXE. Un seul des sujets sans mutation a présenté une importante élastose solaire ainsi qu'une cicatrisation de la rétine, imitant les lésions typiques du PXE. Quatre des 67 sujets hétérozygotes ont eu une biopsie de peau, dont les analyses histopathologique se sont avérées normales.

Conclusion: Dans notre cohorte de patients, le PXE était transmis exclusivement de façon autosomique récessive. La corrélation retrouvée entre le génotype et le phénotype a permis de confirmer les critères diagnostiques majeurs actuels. Le diagnostic clinique peut être difficile, voir impossible, chez des patients atteints d'une élastose solaire importante et/ou d'une dégénérescence maculaire étendue. Dans ces cas, un test moléculaire est nécessaire afin de confirmer le diagnostic de PXE. A notre connaissance, notre étude présentée ici est le premier travail comparant des données cliniques à des données moléculaires dans le domaine du PXE. 
Ce travail a été accepté pour publication dans le British Journal of Dermatology

\section{Clinical and Laboratory Investigations}

Pseudoxanthoma elasticum: evaluation of diagnostic criteria based on molecular data

S. Christen-Zäch ${ }^{1}$, M. Huber ${ }^{1}$, B. Struk ${ }^{3}$, K. Lindpaintner ${ }^{3}$, F. Munier ${ }^{2}$, R. G. Panizzon ${ }^{1}$, D. Hohl $^{1}$.

1 Department of Dermatology and Venereology, CHUV, DHURDV, Lausanne, Switzerland

2 Department of Ophthalmology, Hôpital Jules Gonin, CHUV, Lausanne, Switzerland

3 Cardiovascular Division, Department of Medicine, Brigham and Women's Hospital Boston, USA

\section{KEY WORDS}

ABC-C6- Genodermatosis - Pseudoxanthoma elasticum

\section{ABBREVIATIONS}

PXE: Pseudoxanthoma elasticum - ABC: ATP binding cassette - ATP: Adenosin triphosphate - PCR: Polymerase chain reaction. 


\section{ABSTRACT}

Background: Pseudoxanthoma elasticum (PXE) is a genetic disorder due to mutations in the gene encoding the transmembrane transporter protein adenosine triphosphate binding cassette $(A B C)-C 6$, resulting in calcifications of elastic fibers in the skin, eyes and cardiovascular system.

Objectives: To evaluate the diagnostic criteria for PXE based on molecular data.

Methods: Of 10 families with a positive history of PXE 142 subjects were investigated for clinical symptoms, histological findings and genetic haplotype analysis.

Results: Of these, 25 subjects were haplotypic homozygous for PXE and 23 had typical clinical and histopathological manifestations. Two of the 25 patients showed such marked solar elastosis and macular degeneration that PXE could not be confirmed clinically. Sixty-seven subject were haplotypic heterozygous carriers and 50 haplotypic homozygous unaffected. Of these 117 subjects, 116 showed no cutaneous or ophthalmologic signs of PXE. In one of the 50 haplotypic homozygous unaffected patients important solar elastosis and scaring of the retina mimicked PXE lesions. Only four of the 67 haplotypic heterozygous carriers had biopsies of nonlesional skin; all were histopathologically normal.

Conclusions: In our patients, PXE presents as an autosomal recessive genodermatosis. Correlation of haplotype and phenotype confirmed actual major diagnostic criteria. In patients with marked solar elastosis and/ or severe macular degeneration clinical diagnosis can be impossible and molecular testing is needed to confirm the presence of PXE. To the best of our knowledge our large study compares for the first time clinical findings with molecular data. 


\section{BACKGROUND}

PXE is an inherited connective tissue disorder resulting in abnormal calcification of the elastic tissue network of the skin, eyes and cardiovascular system. The molecular defect was identified in the gene encoding the transmembrane transporter protein adenosine triphosphate binding cassette $(A B C)-C 6{ }^{1-7}$ chromosome $16 p 13.1 .^{1,8}$ This gene encodes a transmembrane transporter protein which belongs to the same family of proteins as those defective in cystic fibrosis or Tangier disease. ABC-C6 is expressed primarily in the liver and the kidney, ${ }^{9}$ suggesting that transporter dysfunction may lead to accumulation of an unknown substrate in the blood causing secondary dystrophic changes of elastic tissues. ${ }^{10}$

Skin lesions consist of yellowish papules or plaques with loss of dermal elasticity. ${ }^{11,12}$ Commonly affected sites are the flexures and periumbilical skin. ${ }^{10}$ Mucous membrane involvement is not rare. ${ }^{13}$ Skin lesions are usually noted in the second or third decade. ${ }^{10}$ Histology of skin lesions shows calcification, alteration and fragmentation of elastic structures in the mid dermis. ${ }^{14}$

Ocular involvement is characterized by angioid streaks, ${ }^{15}$ breaks in the Bruch's membrane, with secondary changes of the retinal pigmented epithelium (peau d'orange), and choriocapillaris. ${ }^{16}$ While the angioid streaks are asymptomatic at first, they become the sites of choroidal neovascularization and subretinal haemorrhages later in life and central loss of vision may occurs in the case of macular involvement. Cardiovascular manifestations usually develop last, and result from slowly progressive calcification of elastic arterial walls. ${ }^{17}$ Reduction of vessel lumen causes ischemia, and excessive fragility of the vessel wall, is responsible for haemorrhage.

To facilitate and unify the clinical diagnosis for PXE, three major diagnostic criteria (characteristic skin involvement, characteristic histopathological features of lesional skin, characteristic ocular disease) and two minor criteria (characteristic dermatopathological features in nonlesional skin, family history of PXE in first-degree relatives) were defined and divided in five categories (I, IIa-d) at the consensuses conference in $1992 .{ }^{18}$ 
The objectives of this study were to evaluate the diagnostic criteria for PXE in the context of precise molecular data. 


\section{PATIENTS AND METHODS}

All subjects with PXE or a positive family history of PXE were eligible for this study. Institutional ethic committee approved consent was obtained from all adults, children when age appropriate or their parents. A detailed family and medical history was noted. All volunteers were subject to clinical examination. Dermatological and ophthalmological findings were photo-documented. Accurate pedigree data comprising at least three successive generations were compiled. For DNA extraction, blood samples were taken from every subject older then 16 years of age; otherwise buccal cells were collected. High molecular weight genomic DNA was extracted from $1 \mathrm{ml}$ ethylenediamine tetraacetic acid-anticoagulated whole blood using a commercially available, adsorption-based method (QIAmp, Qiagen, Valencia, CA, U.S.A), and stored at $-80^{\circ} \mathrm{C}$. The buccal cells were collected according to the protocol of Richards et al. ${ }^{19}$ and the DNA was stored at $4^{\circ} \mathrm{C}$. Sequence and genotype analysis were done as previously reported. ${ }^{2}$

To correlate the extent of clinical alterations, the histopathological findings and the molecular genetic data, cutaneous and histological findings were graded in all subjects. Cutaneous clinical alterations were graded $1+$ if unequivocal but sparse yellow papules had been noted in one or more body folds; $2+$ if numerous typical, confluent yellow xanthoma-like lesions had been observed; and $3+$ if, in addition to these changes, the skin was lax and redundant. Mucosal lesions were considered but not graded.

In 23 adult subjects with typical cutaneous PXE, in four obligate heterozygotes without skin lesions and in three subjects with marked solar elastosis, two 5-mm skin punchbiopsy were taken, under local anaesthesia, from a predilection site, usually in the neck or antecubital fossa. No biopsies were performed in children as they did not show any skin lesions clinically. Biopsies of unaffected skin from four volunteers who did not belong to one of the 10 families of the present study were used as control material. Specimens for light microscopy were fixed in neutral buffered formalin, dehydrated, embedded in paraffin, serially sectioned and stained with haematoxylin-eosin, elastin stain for elastic tissue and Von Kossa stain for calcium phosphates. Stained sections were code-labelled and examined independently by three observers without knowledge of the patient's name 
or diagnosis. The changes consistent with PXE were graded 1+ if small, patchy areas of swollen, fragmented and irregularly clumped elastic fibres were seen in the mid dermis of sections stained by haematoxylin and eosin and elastin stains and if small amounts of calcium were seen in the same areas in serial sections stained by Von Kossa method. A $3+$ score was given if all the elastic fibres in a wide band throughout the mid and lower dermis were affected. Sections were judged to display $2+$ changes if the extent of elastic fibres alterations lay between these two extremes.

The diagnosis of PXE was made on the typical clinical symptoms, on dermatopathological findings and confirmed by molecular genetic haplotype analysis. Cases were classified according to established criteria for PXE on the Consensus Conference $1992 .{ }^{18}$ Only individuals who showed no evidence of cutaneous and/or retinal lesions were considered to be clinically unaffected family members. 


\section{RESULTS}

We investigated 142 subjects, 79 females and 63 males, ages 3-86 years, belonging to 10 families with PXE. Of these, 23 subjects, 15 females and eight males, ages 29-77 years, presented the three major diagnostic criteria of PXE. In three more subjects a marked solar elastosis and severe macular degeneration made it impossible to exclude PXE clinically. These three patients, two females and one male, ages 73-79 years belong to the same family. They are all farmers with important sun exposure and suffer from 'Zermatt macular dystrophy', a dominant, age-related, progressive macular dystrophy. In view of the variable expression and possible late onset of the disease all 142 individuals were included in the genetic analysis. This resulted in the identification of 25 haplotypic homozygous affected individuals, 67 haplotypic heterozygous carriers and 50 haplotypic homozygous unaffected members (Table 1). The pedigree showed a high level of consanguinity and a strictly horizontal pattern of disease prevalence (Fig.1).

In 23 patients, homozygous for PXE, we observed the typical appearance (Fig.2) and distribution of skin lesions. The skin alterations ranged from a few yellow papules to confluent plaques causing redundant folds. They were regarded as slight in three patients, moderate in 14, and severe in six (Table 2). Eleven of the 23 patients showed typical cobblestone-like changes on the buccal mucosa (Fig.3). The age at onset of the skin lesions varied from 12 to 38 years of age in 17 patients. In six patients the skin lesions had never been noted before the study. The skin lesions were first noticed at a mean age of 17 years but a precise diagnose was made only at a mean age of 40 years (Table 3). All 67 subjects, heterozygous for PXE, and 49 of the 50 noncarriers showed no cutaneous or mucosal lesions of PXE.

Independent interpretations of three histological observers regarding presence or absence of PXE were identical for 31 of 34 biopsy sections. The 23 cases, homozygous for PXE, showed the characteristic histological alterations. They were regarded as slight in three patients, moderate in 16 , and severe in four. The correlation between the severity of clinical change and of histology was excellent (Table 2). In four heterozygous carriers for PXE and four volunteers the skin biopsy of nonlesional skin showed no 
histological alterations. In three patients (two homozygous for PXE and one noncarrier) with marked solar elastosis and severe macular degeneration, the clinical and histological interpretation was not clear. Haematoxylin and eosin-stained sections were usually adequate for detection of PXE. Von Kossa staining for calcium was of additional value in confirming subtle lesions, while elastic tissue staining was least useful.

All 23 of homozygous patients for PXE had angioid streaks and peau d'orange pigmentation in both eyes (Fig.4). Eight of the 23 had subretinal neomembranous complications at the posterior pole leading to visual impairment. The fundus lesions were diagnosed at a mean age of 47.8 years and initial ophthalmic complications presented in middle age (Table 3). In the three patients (two homozygous for PXE and one noncarrier) whose clinical and histological interpretation was not clear for PXE, important scarring of the retina made the diagnosis of angioid steaks or peau d'orange impossible. In our series, the ophthalmologic manifestations were responsible for more morbidity than the involvement of any other organ system.

The most common findings of cardiovascular manifestation in the 23 confirmed cases of PXE were hypertension ( $>140 / 90$ ) in 11 patients (48\%) at a mean age of 62.2 years, heart murmurs in $10(43 \%)$ at a mean age of 49.6 , coronary artery disease (CAD) in eight $(35 \%)$ at a mean age of 59.4 , abnormal pedal pulses in three (13\%) at a mean age of 66.7 , intermittent claudication in three $(13 \%)$ at a mean age of 53.7 and strokes in three $(13 \%)$ at a mean age of patients 72.7 years. These patients showed no other risk factor for cardiovascular diseases such as diabetes, tobacco abuse or high blood cholesterol levels. 


\section{DISCUSSION}

In this paper we exploit molecular genetic haplotype analysis to review the validity of clinical and histological criteria to diagnose PXE. The 10 examined families come from isolates of the Swiss Valais canton, a region of genetic nondisperation, offering a unique source for genetic analysis. In this specific region the PXE incidence is approximately 1 in $10^{\prime} 000$ and the heterozygote frequency is 1 in $50 .{ }^{19}$ In general estimates, the prevalence PXE ranges from 1 in $70^{\prime} 000$ to 1 in 1 million ${ }^{10}$.

In our study we found 67 haplotypic heterozygous carriers, 50 haplotypic homozygous unaffected family members and 25 haplotypic homozygous affected individuals. They all showed autosomal recessive inheritance. According to the diagnostic criteria for PXE defined at the consensuses conference held in $1992,{ }^{18}$ we classified 23 of 25 homozygous PXE carriers, clinically as category I (three major criteria). We did not find ocular disease compatible with PXE in any of our haplotypic heterozygous carriers. This allowed us to exclude the presence of clinical type IIa (angioid streaks and two minor criteria), IIb and IIc (angioid streaks and one minor criterion) PXE in our study. Category IId (two minor criteria) PXE was excluded in four of 67 heterozygous carriers, as only four had biopsies of nonlesional skin. Further histological examinations of nonlesional skin would be needed to prove the absence of this category.

We observed that the phenotypic manifestations of PXE can show considerable variability within families. There was no correlation seen between the severity of skin, eye or cardiovascular lesions within the same patient. The genetic patterns studied correlated with the presence or absence of disease but could not explain the different degrees of clinical involvement observed. This may indicate that disease expression is possibly influenced by environmental factors.

The average time between the onset of skin lesions and the diagnosis was 23 years. This prolonged time lapse can be explained by the fact that the majority of patients were not concerned by their skin lesions and did not seek medical advice until their initial ophthalmic lesions presented in middle age (average, 48 years). 
The histopathology of the skin is an important tool to determine the difference between PXE and skin lesions that superficially resemble PXE, such as solar elastosis, cutis laxa, ${ }^{21}$ penicillamine therapy, lesions secondary to vitamin D toxicity or renal disease. It is important to keep in mind that isolated angioid streaks without any other features do not allow a formal diagnosis of PXE. They are observed in many other diseases ${ }^{22}$ and should be regarded as a sign of a possible generalized disorder.

Cardiovascular features in PXE are well described. ${ }^{17,23}$ In the assessment of other organ systems it was surprising that gastrointestinal haemorrhage was not a major problem in our patients, although frequently reported in literature. ${ }^{24}$ We observed a higher incidence of hypertension in patients with PXE than in the mean population. This could be explained by slowly progressive calcification of the elastic arterial wall ${ }^{17}$ with gradual reduction of vessel lumen.

The clinical diagnosis of PXE can be a challenge in the presence of age changes such as solar elastosis or in the late stages of macular degeneration where the angioid streaks may be obscured. Three of our subjects showed such a marked solar elastosis and an important scarring of the retina that we were not able to make the diagnosis of PXE clinically. In this situation a reliable molecular test is helpful. The genetic analysis showed that two of the three had PXE. Diagnosis of the disease is important, although there is no treatment for the basic defect. A prophylactic lifestyle, prophylactic medical monitoring, and genetic counselling are highly recommended.

This report shows an excellent correlation between haplotype and typical clinical manifestation (cutaneous signs, histology of lesional skin and ocular involvement) in PXE. It confirms the validity of the three major clinical diagnostic criteria for category I PXE. One of the two minor criteria, which was a positive family history of PXE, was an important element of diagnose in our study. The other minor diagnostic criteria, which consists of characteristic dermatopathological features in nonlesional skin, was not of any major help in the diagnosis of our patients. Besides, in patients with a positive family history of PXE but without cutaneous or ocular manifestations, it can be difficult to justify a skin biopsy. 


\section{FIGURE LEGENDS}

Table 1 Summary of results

Table 2 Grading of skin lesions and histological features in 23 of 25 homozygous affected individuals.

Table 3 Mean age at clinical manifestation of pseudoxanthoma elasticum.

Fig 1. Pedigree of family 1 ; male (square), female (circle), carrier (dots within), affected (solid square or circle), dead (/), study subjects (arrow), adopted (diamond with square). Fig 2. Thirty-one-years-old patient with pseudoxanthoma elasticum with characteristic yellowish papules and plaques on the neck.

Fig 3. Cobblestone-like changes on the buccal mucosa of a 60-years-old patient with pseudoxanthoma elasticum.

Fig 4. Colour fundus photograph of the left eye of a 52-year-old patient with pseudoxanthoma elasticum with angioid streaks and peau d'orange. 
TABLES AND ILLUSTRATIONS

Table 1

\begin{tabular}{|c|c|c|c|c|c|c|}
\hline \multirow[t]{2}{*}{ Genetic analysis } & \multirow{2}{*}{$\begin{array}{l}\text { Nr of } \\
\text { subjects }\end{array}$} & \multicolumn{3}{|c|}{ Major criteria } & \multicolumn{2}{|c|}{ Minor criteria } \\
\hline & & $\begin{array}{l}\text { skin } \\
\text { signs }\end{array}$ & $\begin{array}{l}\text { + histology in } \\
\text { lesional skin }\end{array}$ & $\begin{array}{l}\text { Ocular } \\
\text { signs }\end{array}$ & $\begin{array}{l}\text { + Family } \\
\text { history }\end{array}$ & $\begin{array}{l}+ \text { histology in } \\
\text { non lesional skin }\end{array}$ \\
\hline $\begin{array}{l}\text { Homozygote for } \\
\text { PXE }\end{array}$ & 25 & 23 of 25 & 23 of 25 & 23 of 25 & 25 of 25 & Not done \\
\hline $\begin{array}{l}\text { Heterozygote } \\
\text { For PXE }\end{array}$ & 67 & 0 of 67 & 0 of 67 & 0 of 67 & 67 of 67 & 0 of 4 \\
\hline Non carrier & 50 & 1 ? of 50 & 1 ? of 50 & 1 ? of 50 & 50 of 50 & Not done \\
\hline Total & 142 & 23 & 23 & 23 & 142 & 0 \\
\hline
\end{tabular}

PXE, Pseudoxanthoma elasticum; ?, marked solar elastosis and retinal scarring did not allow to exclude PXE clinically

Table 2

Skin lesions Histological

features

\begin{tabular}{ccc}
\hline Intensity & No. of & No. of \\
& Subjects & Subjects \\
\hline+ & 3 & 3 \\
\hline++ & 14 & 16 \\
\hline+++ & 6 & 4 \\
\hline Total & 23 & 23 \\
\hline
\end{tabular}


Table 3

Mean age

\begin{tabular}{lcc}
\hline Onset of skin lesions & 17 & years \\
\hline Eye lesions first noted & 47.8 years \\
\hline $\begin{array}{l}\text { Ophthalmologic } \\
\text { complications }\end{array}$ & & \\
\hline Clinical diagnosis of PXE & 40.4 years \\
\hline
\end{tabular}

Fig.1

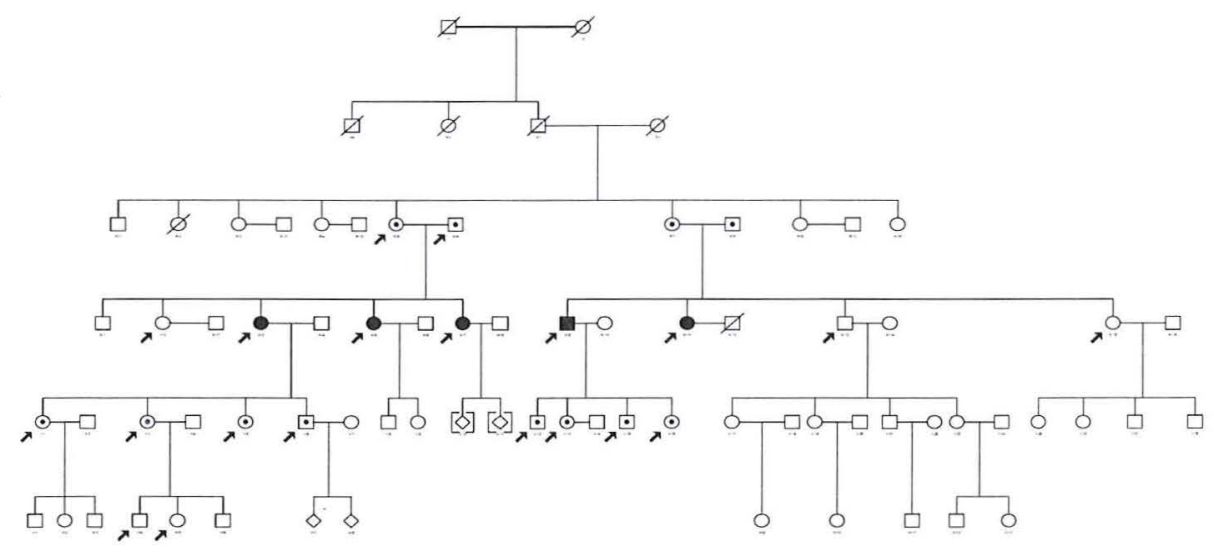

Fig. 2

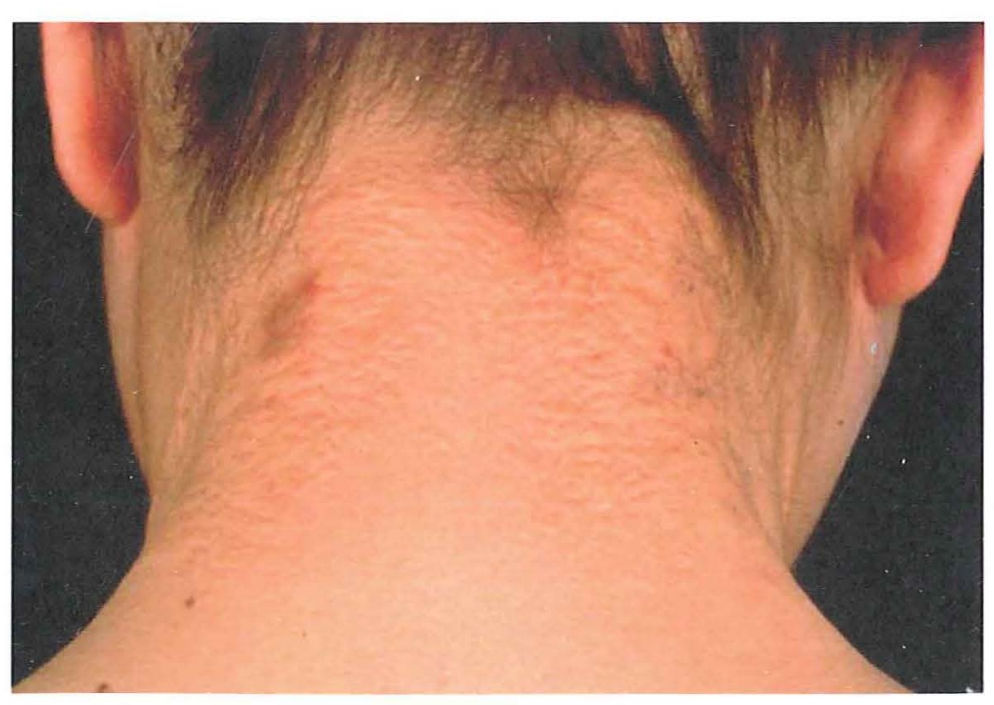


Fig. 3

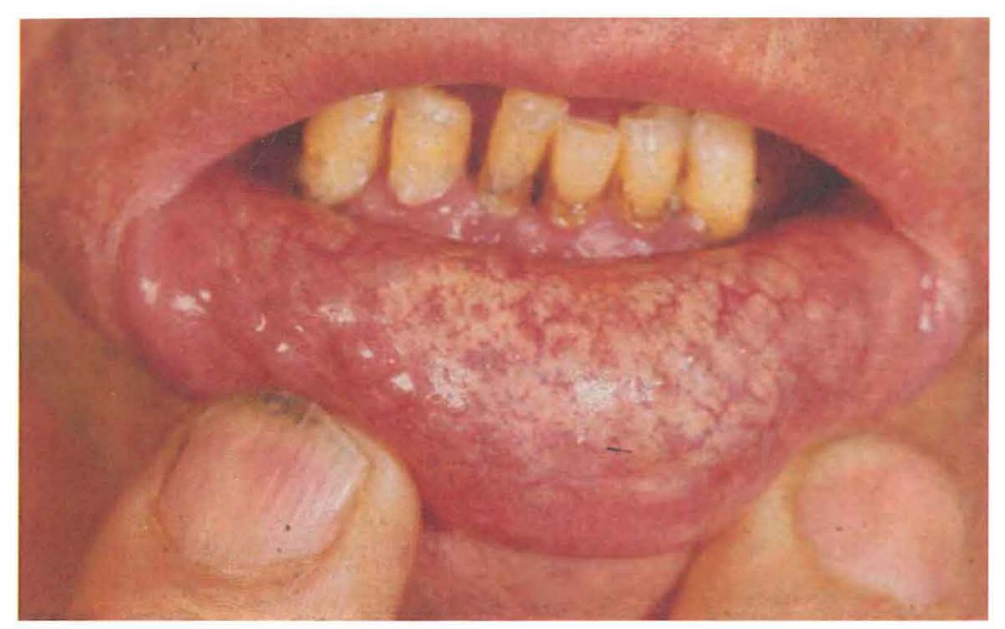

Fig.4

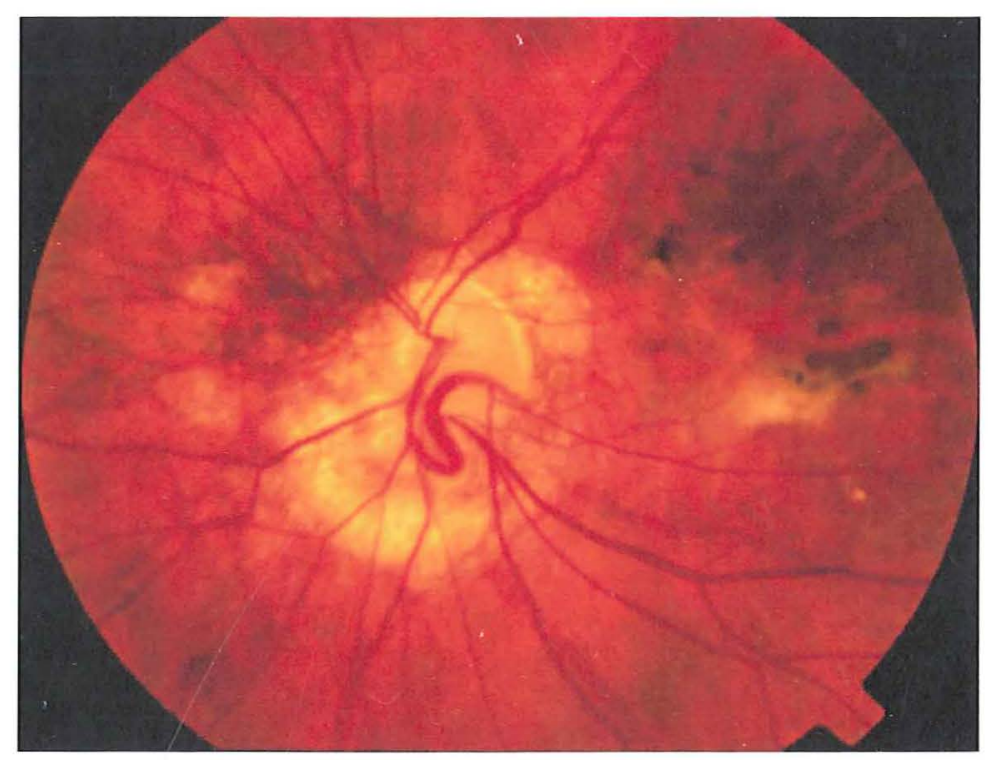




\section{ACKNOWLEDGEMENT}

We thank the members of PXE families for their participation in this study, Patricia

Cornelis for technical assistance, and Dr Peter Joseph Studer for his collaboration. This work was supported by grants from the Swiss National Science Foundation 32-

$065250.01,31-66736.01,31-55849.98$ and the Harvard University (laboratory of Klaus Lindpaintner MD).

\section{DEDICATION}

This work is dedicated to my parents, Claire Gromann and Guido Zäch whose patience, understanding and support enabled me to complete my medical training and this project. I would also like to express my deepest gratitude to my very best friend Christine WenkFurler. 


\section{REFERENCES}

1. Van Soest SS, Jaap. Tijmes, Nel. Sandkuijl, Lodewijk, a. Rommers, Jago. Bergen, Arthur, A, B. A locus for autosomal recessive pseudoxanthoma elasticum, with penetrance of vascular symptoms in carriers, maps to chromosome 16p13.1. genome research $1997 ; 7: 830-833$.

2. Cai L, Struk B, Adams MD et al. A 500-kb region on chromosome 16p13.1 contains the pseudoxanthoma elasticum locus: high-resolution mapping and genomic structure. $\mathrm{J} \mathrm{Mol}$ Med $2000 ; 78: 36-46$.

3. Struk B, Cai $L$, Zach $S$ et al. Mutations of the gene encoding the transmembrane transporter protein ABC-C6 cause pseudoxanthoma elasticum. J Mol Med 2000;78:282-6. 4. Cai L, Lumsden A, Guenther UP et al. A novel Q378X mutation exists in the transmembrane transporter protein $\mathrm{ABCC} 6$ and its pseudogene: implications for mutation analysis in pseudoxanthoma elasticum. J Mol Med 2001;79:536-46.

5. Bergen AA, Plomp AS, Schuurman EJ et al. Mutations in ABCC6 cause pseudoxanthoma elasticum. Nat Genet 2000;25:228-31.

6. Le Saux O, Urban Z, Tschuch $C$ et al. Mutations in a gene encoding an $A B C$ transporter cause pseudoxanthoma elasticum. Nat Genet 2000;25:223-7.

7. Ringpfeil F, Lebwohl MG, Christiano AM, Uitto J. Pseudoxanthoma elasticum: mutations in the MRP6 gene encoding a transmembrane ATP-binding cassette (ABC) transporter. Proc Natl Acad Sci U S A 2000; 97:6001-6.

8. Struk B, Neldner KH, Rao VS, St Jean P, Lindpaintner K. Mapping of both autosomal recessive and dominant variants of pseudoxanthoma elasticum to chromosome 16p13.1.Hum Mol Genet 1997;6:1823-8.

9. Scheffer GL, Hu X, Pijnenborg AC, Wijnholds J, Bergen AA, Scheper RJ. MRP6 (ABCC6) detection in normal human tissues and tumours. Lab Invest 2002; 82:515-8. 10. Neldner KH. Pseudoxanthoma elasticum. Clin Dermatol 1988;6:1-159. 11. Darier J. Pseudoxanthoma elasticum. Monatsheft für Prakt Dermatol 1896;23:609616. 
12. Connor. Pseudoxanthoma elasticum and angioid streaks: review of 106 cases. American journal of medecine 1961;30:537-543.

13. Goette DK, Carpenter WM. The mucocutaneous marker of pseudoxanthoma elasticum. Oral Surg Oral Med Oral Pathol 1981;51:68-72.

14. Mckee PH, Cameron $\mathrm{CH}$, Archer DB, Logan WC. A study of four cases of pseudoxanthoma elasticum. J Cutan Pathol 1977;4:146-53.

15. Knapp. On the formation of dark angioid streaks as an unusual metamorphosis of retinal hemorrhage. Archives of Ophthalmologie 1892;21:289-292.

16. Dreyer R, Green WR. The pathology of angioid streaks: a study of twenty-one cases. Trans Pa Acad Ophthalmol Otolaryngol 1978;31:158-67.

17. Carlborg U. Study of circulatory disturbances, pulse wave velocity and pressure pulses in larger arteries in cases of pseudoxanthoma elasticum and angioid streaks: A contribution to the knowledge of the function of elastic tissue and the smooth muscles in larger arteries. Acta Med Scand (Suppl) $1944 ; 151: 1-209$.

18. Lebwohl M, Neldner K, Pope FM et al. Classification of pseudoxanthoma elasticum: report of a consensus conference. J Am Acad Dermatol 1994;30:103-7.

19. Brenda Richards, Joel Skoletsky, Anthony P. Shuber, et al. Multiplex PCR amplification from the CFTR gene using DNA prepared from buccal brushes/swabs. Hum Mol Genet 1993;2:159-163.

20. Fournier D. [Pseudoxanthoma elasticum a little known syndrome. Clinical and genetic aspects of a case]. Schweiz Rundsch Med Prax 1984;73:183-91.

21. Neldner KH. Pseudoxanthoma elasticum. Int J Dermatol 1988;27:98-100.

22. Gurwood ASM, D.L. Understanding angioid streaks. Journal of the american optometric association 1997;68:309-324.

23. McKusick VA. Pseudoxanthoma elasticum. In: Heritable Disorders of Connective Tissue (McKusick VA, eds) 4th edn. New York: Mosby, 1972.

24. Cunningham JR, Lippman SM, Renie WA, Francomano CA, Maumenee IH, Pyeritz RE. Pseudoxanthoma elasticum: treatment of gastrointestinal hemorrhage by arterial embolization and observations on autosomal dominant inheritance. Johns Hopkins Med J $1980 ; 147: 168-73$. 